\title{
DIFFERENT ASPECTS OF WINDOWS IN BUILDINGS
}

\author{
TAJDA POTRČ OBRECHT ${ }^{1}$,VESNA ŽEGARAC LESKOVAR ${ }^{3}$, MIROSLAV PREMROV ${ }^{3}$, \\ MITJA KOŠIR ${ }^{2}$, MATEJA DOVJAK ${ }^{2}$, ANDRAŽ LEGAT ${ }^{1} \&$ ROMAN KUNIČ ${ }^{2}$ \\ 1Laboratory for Building Physics, Slovenian National Building and Civil Engineering Institute, Slovenia \\ 2Faculty for Civil Engineering and Geodesy, University of Ljubljana, Slovenia \\ 3Faculty of Civil Engineering, Transportation Engineering and Architecture, University of Maribor, Slovenia
}

\begin{abstract}
Windows are an important part of the building envelope. They are important for the energy performance of a building, since they enable passive solar gains, reduce the need for artificial lighting and enable natural ventilation. Passive design strategies are important to enhance the performance of buildings without active systems. The passive solar gains of buildings depend on the orientation of the glazing, the glazing type, the micro location and the form of the building. A study of a single family house with different deviations from the main glazing façade, that differ from the main cardinal orientation, is presented. For each case, the optimal glazing point and the optimal glazing area were examined. A southern orientation remains the most optimal for the chosen climate of Ljubljana. Buildings create an artificial environment with restricted access to daylight. To compensate natural light, artificial lighting sources are installed in the building. To illustrate the influence of windows on the energy performance in an office, the needs for artificial lighting were observed. The energy demand caused by the electricity consumption of artificial lighting is substantial, so the positioning of windows and the visual transmittance are of great importance. Beside the size of the window, its form and height plays an important role. Windows also affect the well-being of the occupants. Most of these effects are connected with providing light, natural ventilation and communication with the outside world. These aspects are also present in sustainable building certification schemes. An overview of the health-related topics presented in different certification schemes connected to windows has been made. We have compared different certification schemes in how they deal with issues of light.
\end{abstract}

Keywords: window, light, energy efficiency, artificial lighting.

\section{INTRODUCTION}

Windows are openings in the envelope of the building that allow the passage of light, energy, sound and air. Several different types of windows exist and generally their performance depends on the size of the window and the properties of the frame and the glazing. Windows have developed from simple openings in the walls to modern, high-performance building components.

The careful design of windows can be beneficial in terms of energy and for the well-being of occupants. Heat gains through windows are beneficial since they are able to reduce the energy needs for heating the building in climates where heating is the major energy burden. High energy gains can also result in additional energy loads for cooling the building in case of overheating. Daylight through the window contributes to the reduction of lighting energy consumption in buildings. This can be considered as a passive strategy for reducing energy use and improving visual comfort. Beside energy reduction, it also influences the well-being of the occupants. Windows provide access to daylight, which improves the visual quality indoors, but daylight also has non-visual aspects. It is responsible for sleeping patterns, hormone secretion, etc.

\section{ENERGY FLOW THROUGH WINDOWS}

The energy flow through the building envelope depends on the circumstances of the physical environment; for example, external temperature, solar radiation, wind, the surrounding buildings and plants, etc. The shape of the building, the percentage of transparent surfaces, the orientation, etc. are also important [1]. The application of passive design measures are 
able to improve the energy efficiency of a building [2]. With the correct design, we are able to regulate the solar gains through the windows and hereby decrease the energy consumption needed for heating and cooling the building. The solar gains do not only depend on the position, size and shading of the window, but also on the glazing properties. The solar gains are influenced by the solar transmittance (g-value) of the window, which depends on the number of glazing panes, glazing pane thickness, air gap between the glazing panes, distance between them and gas filling. In a cold climate, it is desired that the glazing has a low emittance and a high g-value and visual transmittance (VT). In warm climates, there is a high possibility that the buildings' thermal properties are less important and a low g-value is desired [3].

Various researchers have studied the optimal share of glazing on a façade for the chosen locations. The focus was mostly on the main cardinal directions. The south orientation of the main longitudinal façade has proven to be optimal for the northern hemisphere and a climate with hot summers and temperate-to-cold winters. This was confirmed in different studies; for example, Leskovar and Premrov [4] for Ljubljana, Jaber and Ajib [5] for the Mediterranean region, etc. If we move the main façade to the east or to the west, the glazing share should decrease. The better the U-value of the glazing share is, the more glazing area we can have on the long façade of the building, since the transmission loss is not so big and the optimum shift to a higher glazing-to-wall area ratio (AGAW). Also, lower g-values provide less solar gains and, therefore, the glazing with lower solar transmittance has lower optimal AGAW. These findings are important for building developers and investors, since optimal glazing shares enable energy savings and, consequently, also financial savings.

In a real situation we rarely have the opportunity to follow the main cardinal direction, but have to orientate the house corresponding to its context and surrounding. In the following study, we present how the optimal glazing shares changes when we tilt the main façade towards the east and the west for less than 90 degrees.

\subsection{Parametric study of a family house for different orientations}

The study model is a house with the external dimensions $11.46 \mathrm{~m} \times 7.86 \mathrm{~m}$. The house has a ground floor and an upper mansard floor. This is a typical typology in Slovenia. For the purpose of the study, the glazing was eliminated on all façades, except on one longitudinal façade, named the main façade. Due to this elimination, it was possible to examine the effect of the windows on the long, originally south, façade, without misleading solar and transmission gains of the other façade. The study was performed for glazing with different $\mathrm{U}$-values and the g-value 0.60 .

The climate conditions of Ljubljana were selected for the study. Ljubljana is the capital of Slovenia and is located at the latitude of $46^{\circ} 03^{\prime}$ North and a longitude of $14^{\circ} 31^{\prime}$ east, and has an altitude of $298 \mathrm{~m}$.

The optimal point is determined as the point where the sum of the heating and the cooling energy is the lowest. Generally, the optimal glazing share shifts towards smaller AGAWs when we tilt the house toward the east or the west. Similar results were obtained by Leskovar and Premrov [4], [6], who were studying the main cardinal directions. This study also confirms that the south orientation of the main façade is the most favourable. Lower U-values of glazing allow higher AGAW ratios. Generally, for all orientation the optimal AGAW point and the AGAW optimal area is the highest in the case of $U_{g}=0.50 \mathrm{~W} / \mathrm{m}^{2}$ and the lowest in the case $U_{g}=0.70 \mathrm{~W} / \mathrm{m}^{2}$. When we increase the U-value of the glazing, we have a higher transmission loss and the optimal glazing area is decreasing. The slightly higher annual solar 

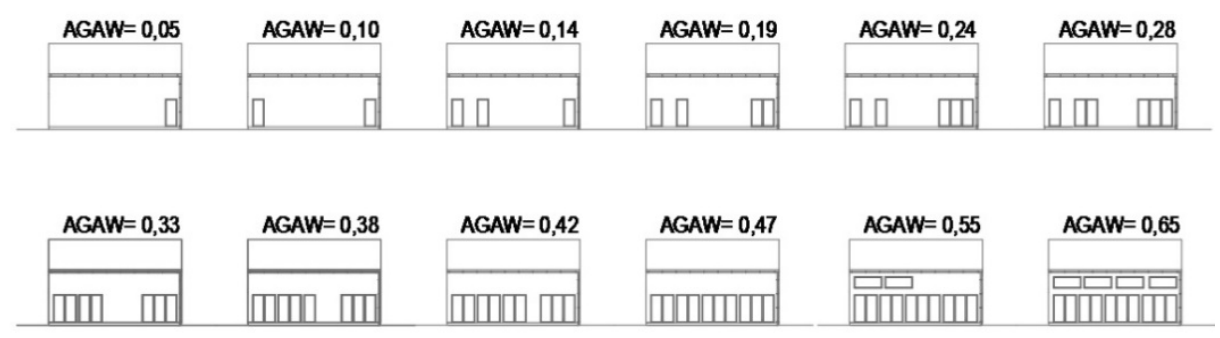

Figure 1: Studied glazing ratios (AGAW) of the main façade.

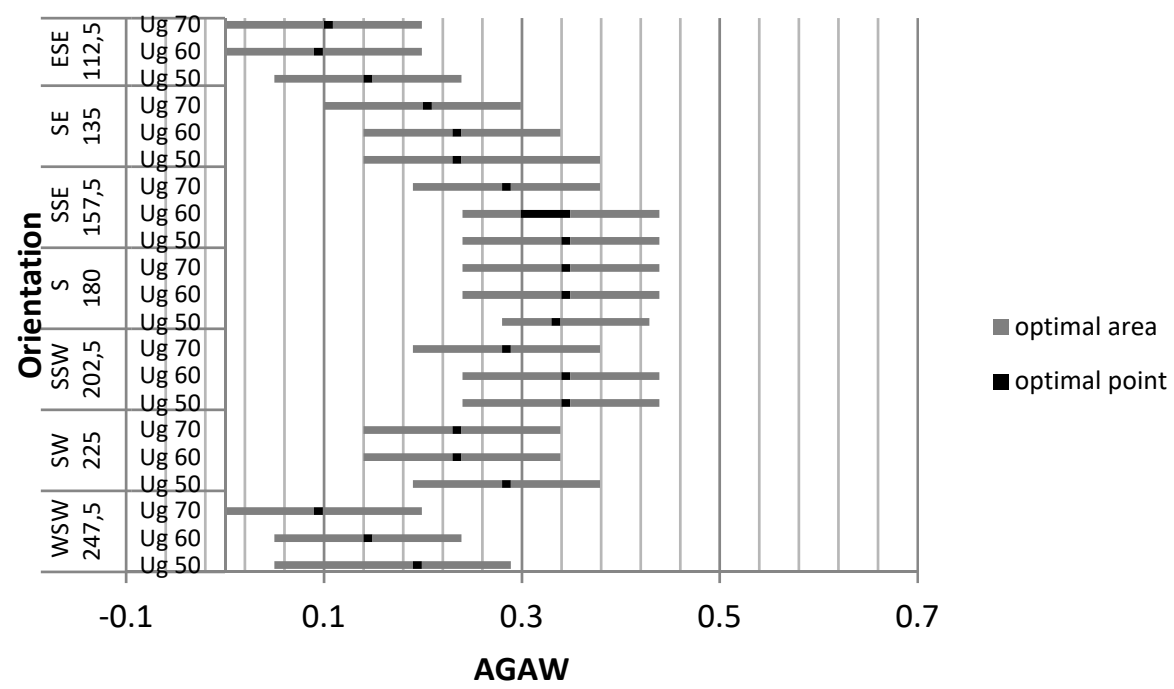

Figure 2: Optimal glazing points and areas for different glazing ratios (AGAW) of the main façade.

gains to the west enable higher glazing ratios for orientations towards to the west as to the east for the same decline from the south.

\section{ARTIFICIAL LIGHTING}

Solar radiation reduces the use of artificial lighting. It is estimated that artificial lighting can contribute $20-35 \%$ to the overall energy consumption of a building. With the correct positioning of the glazing, the energy savings of the lighting can reach $7 \%$ when $10 \%$ of the façade is glazed and we consider the threshold illuminance of $250 \mathrm{~lx}$ [7]. Artificial lighting consumes a large share of energy, especially in office buildings. In the following study, we have observed how the window size and type influences the needs of artificial lighting.

\subsection{Study of artificial lighting needs in a typical office}

The study model is an office that is $3 \mathrm{~m}$ wide, $4 \mathrm{~m}$ long and $3 \mathrm{~m}$ high. It has one external wall with a length of $3 \mathrm{~m}$, and other walls are adjacent. The glazing types are different depending 
on their solar transmittance (g-value), VT, visual transmissivity and thermal transmittance (U-value). The smaller size $1.23 \times 1.48 \mathrm{~m}$ is the standard size defined according to the standard EN 14351-1. The area of glazing area of floor ratio AGAF is $15 \%$. The second size is the prolonged version of the standard size measuring $1.23 \times 2.13 \mathrm{~m}$. This size is suitable according to Slovenian regulations that the AGAF should be at least $20 \%$ - in our case, $22 \%$. The frame is the same in all cases and has a width of $0.08 \mathrm{~m}$. The different glazing types studied are presented in Table 1.

There are two lighting devices in the offices, placed $1 \mathrm{~m}$ and $2 \mathrm{~m}$ away from the external wall. It is observed that the lights are switched out automatically when the illuminance at the point below the lighting device falls below $250 \mathrm{~lx}$. The lighting device is longitudinally parallel to the external wall and has an electric lighting power of $39 \mathrm{~W}$. The energy use of the lighting devices was calculated with the Diva4Rhino simulation tool, which was used to predict the annual energy demand for artificial lighting, based on the dynamic weather conditions for the given year and location.

It is obvious and logical that for all of the observed cases the light device placed further from the window has to be turned on more often. The demand for artificial lighting is also depending on the VT of the glazing. If the VT is high, there is less need for artificial lighting. The lightening demand is calculated during the working schedule between 8:00 and 18:00. Because the offices are mainly occupied during the morning hours, the lighting demand for offices orientated to the east is the smallest. In the case study, the south was the second-best orientation in terms of artificial lighting. In most cases, the north orientation performed better than the west orientation.

Table 1: Glazing properties.

\begin{tabular}{|l|l|l|l|l|}
\hline Name & $\begin{array}{l}\text { Visual } \\
\text { transmissivity } \\
{[-]}\end{array}$ & $\begin{array}{l}\text { Visual } \\
\text { transmittance } \\
{[-]}\end{array}$ & $\begin{array}{l}\text { g-value } \\
{[-]}\end{array}$ & $\begin{array}{l}\text { U-value } \\
{\left[\mathrm{W} / \mathrm{m}^{2} \mathrm{~K}\right]}\end{array}$ \\
\hline 52 & 0.52 & 0.48 & 0.36 & 1.16 \\
\hline 65 & 0.65 & 0.61 & 0.42 & 1.05 \\
\hline 88 & 0.88 & 0.81 & 0.62 & 1.06 \\
\hline
\end{tabular}

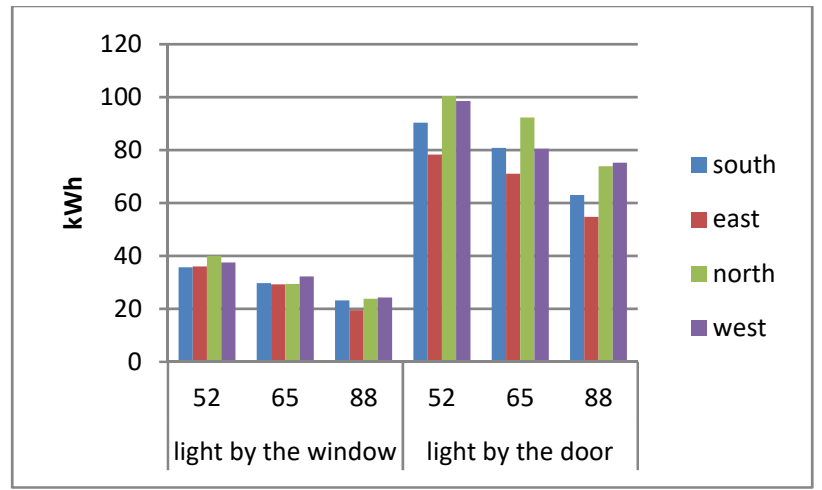

Figure 3: The electricity used by the chosen lighting devices for different orientations and glazing types for the small vertical window. 


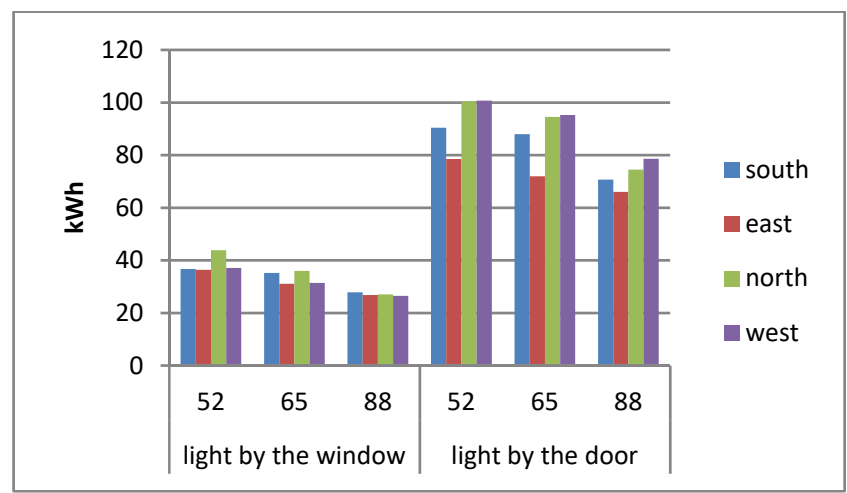

Figure 4: The electricity used by the chosen lighting devices for different orientations and glazing types for the large vertical window.

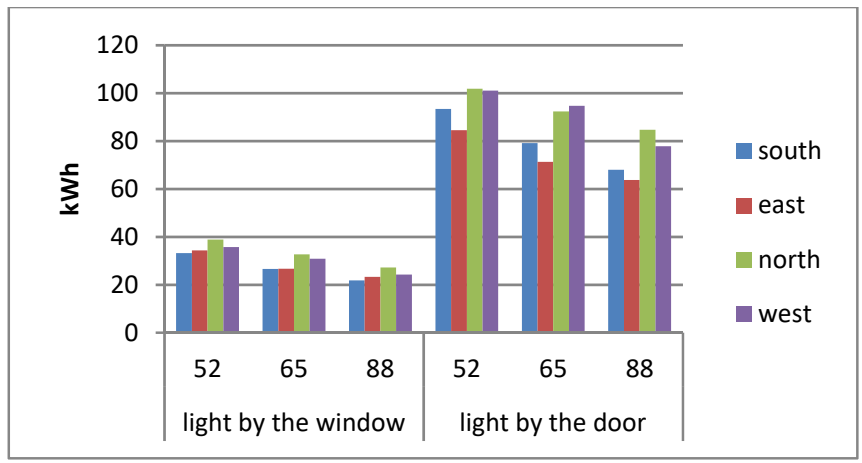

Figure 5: The electricity used by the chosen lighting devices for different orientations and glazing types for the small horizontal window.

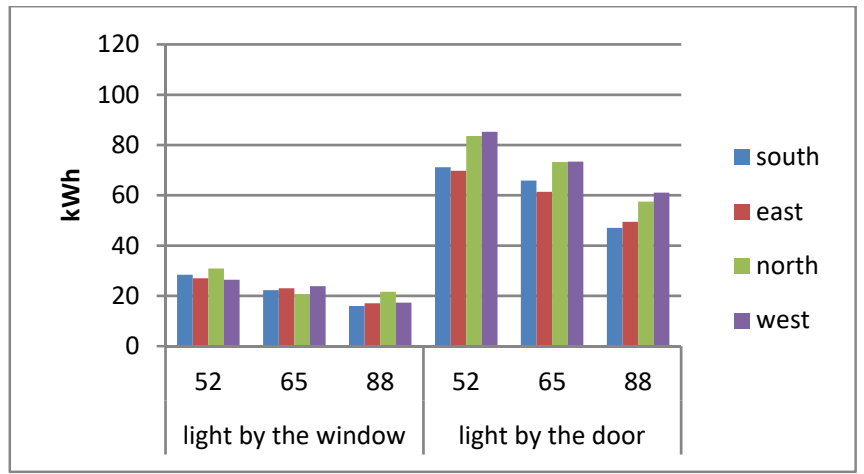

Figure 6: The electricity used by the chosen lighting devices for different orientations and glazing types for the large horizontal window. 
The demand for artificial lighting for both light devices is the lowest for the large horizontal window. In the case of the large vertical window and the small horizontal window, the energy demand for the lighting device by the door is similar, but the lighting demand for the light by the window is a bit smaller for the large vertical window. When we compare the large vertical and the small vertical window, the lighting demand is higher for the larger window. This is because the small window has a parapet wall and is placed higher, so the light reaches deeper in the space and provides a better illuminance. The part of the window near to the ground does not contribute much to the better illuminance of the space.

\section{VISUAL AND NON-VISUAL ASPECTS OF LIGHT THROUGH WINDOWS}

Windows are also important in terms of providing natural light and ensuring well-being for the occupants. Bellia et al. [8] found that inappropriate lighting conditions can influence the standard human rhythm and may reduce the performance of the occupants. It is important to compensate the lack of natural lighting with artificial lighting devices. It is often stated that artificial light is able to compensate the visual aspects, but not the non-visual aspects of light. The non-visual aspects are responsible for sleeping patterns, daily patterns of hormone secretion, body temperature cycles, etc.

Building certification schemes are used to evaluate certain aspect of buildings. They assign a score to different topics and weigh the different results to a single score. The visual aspects of lighting are often simulated and calculated, while the non-visual aspects are rarely assessed. We have compared different building certification schemes. Existing certification schemes like LEED, BREEAM, DGNB etc. are developed as a tool to measure the sustainability of the buildings [9]. WELL is a building certification scheme specialized in the health and well-being of the occupants. We compared the following certification schemes: LEED, BREEAM, DGNB and WELL.

\subsection{Light in the existing building certification schemes}

The LEED [10] certification scheme is from the USA and is the most commonly used certification scheme. It evaluates aspects connected to natural light provided through windows, but also artificial lighting. The topics that deal with light are Interior lighting, Daylighting and Quality Views. The topic Interior lighting is designed to promote people's productivity, comfort and well-being by providing high-quality lighting. The occupants have to have the possibility to adjust the light. The lights have to be positioned between 90 and 45 degrees form nadir and have an illuminance of less than $2500 \mathrm{~cd} / \mathrm{m}^{2}$, the lights have to provide a colour-rendering index higher than 80 and the majority of light has to have a rated life higher than 24,000 hours. The reflectance of the surfaces is also prescribed.

The DGNB [11] certification scheme evaluates if there is daylight provided. The visual connection to the outside is evaluated, as well as the avoidance of glare, the quality of artificial lighting, the colour rendering and the illuminance.

The BREEAM [12] certification prescribes minimum daylight factors and illuminance. It also evaluates measures for glare minimization, whether views to the outside are provided and the quality of artificial lighting. The window-to-wall ratio is also suggested. Furthermore, personal control over lighting devices is desired.

The WELL [13] standard is specialized in the health and well-being of the occupants. The minimal illuminance of $215 \mathrm{~lx}$ should be maintained. Lights that support circadian rhythm are preferred. Electric and sunlight glare should be avoided since they cause discomfort. An adequate colour-rendering index should be provided. Additional points are gained for automated shading systems and the dimming of lights, simulating daylight conditions, etc. 
While BREEAM and LEED emphasize the importance of views to the outside, in WELL certification, having a view to the outside has less meaning and is only briefly mentioned in the subsection 'Right to light' where it evaluated whether the majority of the workstation or occupied spaces are within a certain distance from the window. The results are illustrated in Table 2.

\section{CONCLUSIONS}

The choice of the right window size, orientation and other window properties can greatly influence the energy consumption of the building for different climates. Beside the thermal transmittance of glazing, the solar gains are also very important, and thus, also the orientation of the window. For the northern hemisphere, different researcher for the areas with hot summers and cold winters showed that the south-facing windows are often the most effective since they enable larger solar gains. A lot of studies analyse the main cardinal directions, but in reality, the façades are often only slightly tilted from the main cardinal directing. The presented study showed that the south orientation enables the highest share of glazing. When we move the main façade towards west or east, the area of glazing should decrease. The better the U-value of the glazing share, the more glazing area we can have on the long façade of the building, since the transmission loss is not so big and the optimum shift to a higher AGAW. Lower g-values provide less solar gains and generally the optimal glazing area is smaller compared to higher U-values. This finding is important for informing designers of homes about the optimal glazing areas for the façade, but also for understanding how different glazing properties affect the size of the optimal glazing share.

The artificial lighting needs are especially important for office buildings, since the energy consumption of artificial lighting can be as high as $20 \%$ or more of all of the energy needs. Not only the orientation and the size of the window are important, but also the geometry and the parapet high influence light transmittance. To reduce the lighting needs, it is optimal if the windows are placed at the proper height and are wide.

Windows are important in terms of energy use, as well as in terms of the well-being of the occupants. The existing building certification schemes evaluate which criteria connected to light should be fulfilled to obtain the certification. We have found that the topics connected with visual lighting needs and glare are well covered while the non-visual aspects connected to light are rarely assessed.

Table 2: Light aspects in different certification schemes.

\begin{tabular}{|l|l|l|l|l|}
\hline & LEED & DGNB & BREEAM & WELL \\
\hline Visual lighting design & $\mathrm{X}$ & $\mathrm{X}$ & $\mathrm{X}$ & $\mathrm{X}$ \\
\hline Circadian lighting design & & & & $\mathrm{X}$ \\
\hline Electric light glare control & & & $\mathrm{X}$ & $\mathrm{X}$ \\
\hline Solar glare control & & $\mathrm{X}$ & $\mathrm{X}$ & $\mathrm{X}$ \\
\hline $\begin{array}{l}\text { Low-glare workstation } \\
\text { design }\end{array}$ & & & & $\mathrm{X}$ \\
\hline Colour quality & $\mathrm{X}$ & $\mathrm{X}$ & & $\mathrm{X}$ \\
\hline Surface design & $\mathrm{X}$ & & & $\mathrm{X}$ \\
\hline $\begin{array}{l}\text { Automated shading and } \\
\text { dimming controls }\end{array}$ & & & & $\mathrm{X}$ \\
\hline Right to light & & & $\mathrm{X}$ & $\mathrm{X}$ \\
\hline Daylight modelling & & & & $\mathrm{X}$ \\
\hline Daylighting fenestration & & & & $\mathrm{X}$ \\
\hline
\end{tabular}


The choice of windows should also focus on the thermal properties connected with energy transmittance and artificial lighting use, as well as on the visual and non-visual aspects of light in the building.

\section{ACKNOWLEDGEMENTS}

All of the research presented here is part of larger research projects that are in the process of being published.

This work was partly supported by the European Regional Development Fund, Research and Development Programmes (TRL 3-6), Sustainable and Innovative Construction of Smart Buildings (smart buildings and home, including wood chain: TIGR4smart) (Programme C3330-16-529003).

\section{REFERENCES}

[1] Bektas Ekici, B. \& Aksoy, U.T., Prediction of building energy needs in early stage of design by using ANFIS. Expert Syst. Appl., 38(5), pp. 5352-5358, 2011.

[2] Al-Zubaidy, S., Passive design of buildings for extreme weather environment, http://ejournal.undip.ac.id/index.php/ijred/article/view/4486. Accessed on: $4 \mathrm{Jul}$. 2017.

[3] Karlsson, J.U. \& Roos, A., Annual energy window performance vs. glazing thermal emittance - the relevance of very low emittance values. Thin Solid Films, 392, pp. 345-348, 2001.

[4] Leskovar, V.Ž. \& Premrov, M., Influence of glazing size on energy efficiency of timber-frame buildings. Constr. Build. Mater., 30, pp. 92-99, 2012.

[5] Jaber S. \& Ajib, S., Optimum, technical and energy efficiency design of residential building in Mediterranean region. Energy Build., 43(8), pp. 1829-1834, 2011.

[6] Leskovar, V.Ž. \& Premrov, M., An approach in architectural design of energy-efficient timber buildings with a focus on the optimal glazing size in the south-oriented façade. Energy Build., 43(12), pp. 3410-3418, 2011.

[7] Acosta, I., Munoz, C., Campano, M.A. \& Navarro, J., Analysis of daylight factors and energy saving allowed by windows under overcast sky conditions. Renew. Energy, 77, pp. 194-207, 2015.

[8] Bellia, L., Bisegna, F. \& Spada, G., Lighting in indoor environments: visual and nonvisual effects of light sources with different spectral power distributions. Build. Environ., 46(10), pp. 1984-1992, 2011.

[9] Ding, G.K.C., Sustainable construction-The role of environmental assessment tools. J. Environ. Manage., 86(3), pp. 451-464, 2008.

[10] US Green Building Council, LEED BD+C: New Construction v4, 2014. [Online]. http://www.usgbc.org/credits/homes?page=1. Accessed on: 10 Nov. 2016.

[11] DGNB, DGNB New Construction Residential, 2015.

[12] BRE Global, BREEAM New Construction 2016, 2016. [Online]. http://www.breeam.com/new-construction. Accessed on: 10 Nov. 2016.

[13] WELL. [Online]. https://www.wellcertified.com/. Accessed on: 4 Nov. 2016. 